\title{
OBSERVASI HILĀL DI INDONESIA DAN SIGNIFIKANSINYA DALAM PEMBENTUKAN KRITERIA VISIBILITAS HILA $\bar{L}$
}

\author{
Muh. Ma'rufin Sudibyo \\ Lembaga Pengkajian dan Pengembangan Ilmu Falak - Rukyatul Hilal Indonesia \\ (LP2IF-RHI) Yogyakarta \\ e-mail: marufins@yahoo.com
}

\begin{abstract}
This research aim to analyze of the data generating a modern empirical visibility criterion called Indonesia visibility criteria (RHI criteria) in the form aD $\geq 0,099 \mathrm{DAz}^{2-}$ $1,490 \mathrm{DAz}+10,382$. Although based on a local database, but these criterion are consistent with the international visibility databases such as Yallop and ICOP, along selected only for data sourced from the tropical region. These criterion also were consistent when compared to the tropical visibility database not from Indonesia. So this criteria is the national visibility criterion (for Indonesia) and also regional visibility criterion (tropical region). Comparative analysis showed that although different in form than modern visibility criterion that have similar variables as Fotheringham-Maunder and Bruin criterion, but the form of the Indonesia visibility criterion (RHI criterion) may still be accepted because it is supported by the recent observation data. The difference in shape is due to the Indonesia visibility criterion (RHI criterion) does not distinguish between optical aid-based observations with naked-eye observations.
\end{abstract}

[]

Penelitian ini bertujuan untuk menganalisis kriteria visibilitas modern empiris yang disebut kriteria visibilitas Indonesia (kriteria RHI) dalam bentuk $\mathrm{a}_{\mathrm{D}} \geq 0,099 \mathrm{DAz}^{2}-1,490$ $\mathrm{DAz}+10,382$. Meski berdasarkan basis data lokal, namun kriteria ini konsisten dengan basis data visibilitas internasional seperti Yallop dan ICOP, sepanjang diseleksi hanya untuk data-data yang bersumber dari kawasan tropis. Kriteria ini pun tetap konsisten kala dibandingkan dengan basis data visibilitas tropis yang bukan berasal dari Indonesia. Sehingga kriteria ini merupakan kriteria visibilitas nasional (Indonesia) dan regional (kawasan tropis). Analisa komparatif menunjukkan, meski berbeda bentuk apabila dibandingkan kriteria visibilitas modern dengan variabel sejenis seperti kriteria Fotheringham-Maunder dan Bruin, namun bentuk kriteria visibilitas Indonesia (kriteria RHI) tetap bisa diterima karena didukung oleh data-data observasi terkini. Perbedaan bentuk lebih disebabkan karena kriteria visibilitas Indonesia (kriteria RHI) tidak membedakan antara observasi berbasis alat bantu optik dengan yang tidak.

Keywords: hilāl, kriteria visibilitas, kriteria visibilitas Indonesia, kriteria RHI, kontras

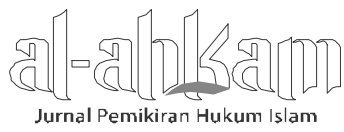




\section{Pendahuluan}

Salah satu problem internal Umat Islam masa kini yang senantiasa mengemuka menjelang bulan suci Ramadhan, Syawwal dan Zulhijjah adalah perbedaan penetapan tanggal 1 Hijriyyah, yang berimplikasi pada terjadinya perbedaan memulai ibadah puasa Ramadhan maupun merayakan Idul Fitri dan Idul Adha. Perbedaan itu telah berlangsung dalam kurun waktu cukup lama dan menjadi problem klasik. Demikian halnya di Indonesia, di mana perbedaan bahkan menyulut keriuhan psikologis dan sosial-politis dalam merayakan Idul Fitri 1432 H (2011 TU) dan memulai puasa Ramadhan 1433 H (2012 TU).

Salah satu penyebabnya terletak pada perbedaan dalam mendefinisikan hilāl, baik secara empiris maupun sosio-psikologis. Secara empiris umat Islam masa kini telah "menceraikan" model matematis tentang gerak dan posisi bulan (hisāb) dengan data observasi yang dapat dipercaya dan diulangi di kemudian hari asal syarat-syaratnya terpenuhi (ru'yat). Hisāb dan ru'yat kini diposisikan menempati kubu saling berseberangan dengan pendukungnya masing-masing. "Perceraian" ini sulit dinalar mengingat Islam adalah agama yang menopang perkembangan ilmu pengetahuan, sementara dalam ilmu pengetahuan sendiri hubungan antara data-data penelitian dengan model matematis prediktifnya yang membentuk sebuah teori demikian erat. Suatu teori dapat terkoreksi jika data-data observasi terkini menunjukkan perlunya perbaikan dalam model matematis prediktifnya dan sebaliknya suatu model matematis mampu meningkatkan kualitas observasi ke tingkat lebih tinggi sehingga menghasilkan serangkaian data lebih bermutu dibanding sebelumnya.

Pada ranah sosio-psikologis terbentuk persepsi mațla lokal dan global. Mațla' lokal beranggapan hisāb ataupun ru'yat hanya berlaku untuk wilayah-wilayah yang menempati kawasan yang sama. Sebaliknya mațla' global berpendapat hisāb atau ru'yat berlaku untuk seluruh wilayah di permukaan bumi tanpa terkecuali. Beda persepsi ini menghasilkan beda pendapat tentang sifat kalender, apakah regional ataukah global. Begitupun tiap persepsi juga tidak tentu bulat dalam mengusung pendapatnya. Dalam hal mațla' lokal misalnya, terdapat perbedaan pendapat tentang penerapan konsep wilāyat al-ḥukmi, yakni konsep dimana hasil hisāb ataupun ru'yat diberlakukan secara homogen bagi satu wilayah administratif tertentu (misalnya negara) meski hisāb positif maupun ru'yat positif hanya mencakup sebagian atau sebagian kecil wilayah tersebut. 
Dalam mațla' global, yang mengusung adagium satu hari sama dengan satu tanggal Hijriyyah, kerap dijumpai kekacauan dalam mendefinisikan hari terutama setelah berlakunya keputusan Konferensi Meridian Internasional 1884 yang menetapkan posisi garis-garis bujur di bumi dengan garis $0^{\circ}$ melintasi Greenwich (Inggris) dan garis $180^{\circ}$ sebagai Garis Tanggal Internasional (International Date Line) dalam kalender Gregorian (Shamsiyyah/Tarikh Umum) ditetapkan melintasi tengah-tengah Samudera Pasifik. Munculnya kerancuan akibat pencampuradukan definisi hari versi kalender Gregorian yang menetapkan transisi hari pada pukul 24:00 waktu setempat di satu sisi dengan definisi hari versi kalender Hijriyyah yang menetapkan pergantian hari kala matahari terbenam waktu setempat di sisi lain. Campuraduk ini berimbas pada munculnya adagium aneh: satu hari sama dengan satu tanggal Hijriyyah sama dengan satu tanggal Shamsiyyah.

\section{Problematika Hisab Rukyat di Indonesia}

Umat Islam di Indonesia terbagi ke dalam dua kubu berbeda dalam penentuan tanggal 1 Hijriyyah, yakni kubu hisāb dan ru'yat. Hisab diantaranya digunakan oleh Muhammadiyah dan Persis sementara ru'yat diadopsi diantaranya oleh Nahdlatul 'Ulama'. Secara kuantitatif warga Muhammadiyah dan Nahdlatul 'Ulama menempati proporsi terbesar umat Islam di Indonesia, sehingga perbedaan penentuan tanggal 1 Hijriyyah antara keduanya berimplikasi signifikan terhadap perbedaan sikap umat Islam di Indonesia. ${ }^{2}$

Muhammadiyah menggunakan hisāb sebagai pedoman penyusunan kalender Hijriyyah dan bukan semata untuk penentuan bulan-bulan suci dengan mengacu Kitab Keputusan Wiradesa 1973, meski upaya membakukan hisāb telah dirintis sejak masa K.H. Ahmad Dahlan. ${ }^{3}$ Hisāb yang digunakan adalah ḥisāb haquīqīi

1Djamaluddin, "Re-evaluation of Hilāl Visibility in Indonesia", dalam Warta LAPAN, Vol. 2 no. 4, 137-138, Oktober 2000, h. 137.

2Perbedaan 1 Hijriyyah khususnya pada periode pra-1998 juga disebabkan faktor sosio-politis: 'perlawanan sunyi' Nahdlatul 'Ulama terhadap rezim Orde Baru, lihat dalam Izzudin, Fiqih Hisab Rukyah (Jakarta: Erlangga, 2009), h. 56.

${ }^{3}$ Azhari, 2009, http://www.ilmufalak.org/, diunduh pada 10 Desember 2009.

4Yakni sistem hisāb yang berdasarkan pada kondisi bulan secara apa adanya, bukan berdasarkan pendekatan (taqrib) dengan menggunakan nilai rata-rata. Lihat dalam Badan Hisab Rukyat Kemenag Pusat, Almanak Hisab Rukyat (Jakarta: DirektoratJenderal Bimbingan Masyarakat Islam Kementerian Agama RI, 2010), h. 67. 
dengan "kriteria" wujūd al-hilāl 5 tanpa wilāyat al-ḥukm. Dalam "kriteria” ini, bulan diasumsikan berada dalam fase hilāl ketika puncak cakram bulan tepat bersentuhan dengan horizon barat kala matahari terbenam, yang secara matematis diterjemahkan sebagai Lag $\geq-2$ menit secara geosentrik. Apabila garis Lag $=-2$ menit melintasi Indonesia, maka daerah yang terletak di sisi timur garis tersebut akan memasuki tanggal 1 Hijriyyah sehari lebih lambat ketimbang daerah yang ada di sisi baratnya. Muhammadiyah tergolong konsisten menggunakan hisāb meski tetap terdapat deviasi lokal. ${ }^{6}$

Nahdlatul 'Ulama awalnya menggunakan ru'yat tanpa pembatasan dan hanya untuk menetapkan tanggal 1 Ramadhan, Syawwal dan Zulhijjah, khususnya pada periode pra-1998 meskipun beberapa kitab ilmu falak rujukan dengan jelas memuat batasan minimal agar bulan bisa disebut hilāl ${ }^{7}$. Saat itu setiap laporan ru'yat akan diterima tanpa verifikasi untuk memastikan apakah yang terlihat berupa hilāl asli8 ataukah hilāl palsu9 . Pasca 1998 barulah Nahdlatul 'Ulama menerapkan batasan dan ru'yat mulai dilaksanakan dengan berbasis hisāb. Tidak semua laporan hilāl langsung diterima karena harus diproses lewat Lajnah Falakiyyah $^{10}$ untuk kemudian diputuskan pengurus pusat (PBNU). Namun keputusan penetapan tanggal 1 Hijriyyah tetap berdasarkan ada tidaknya hilāl secara wilāyat al-hukm. Kini ru'yat di kalangan Nahdlatul 'Ulama dilakukan setiap saat penentuan tanggal 1 Hijriyyah (tanpa dibatasi hanya untuk Ramadhan, Syawwal

5Istilah yang tepat adalah wujūd al-qamar (lahirnya bulan), sebab pada kondisi tersebut secara ilmiah bulan sudah pasti telah lahir atau terbit, namun tidak demikian dengan hilāl, lihat Djamaluddin, Re-evaluation of Hiläl Visibility in Indonesia, 2000, h. 137.

${ }^{6}$ Sebagaimana pengamatan penulis pada aktivitas PC Muhammadiyah Gombong era 2007-2009.

${ }^{7}$ Misalnya dalam kitab Sullam an-Nayyirayn, yang dipelajari oleh hampir semua pesantren di lingkungan $\mathrm{NU}$, yang membatasi hilāl sebagai bulan dengan irtifă' (tinggi) minimal $5^{\circ}$.

${ }^{8}$ Hilālasli merupakan istilah penulis bagi bulan sebagai hilālyang sebenarnya.

${ }^{9} \mathrm{Hilāl}$ palsu adalah istilah penulis untuk benda langit terang yang mirip hilāl dalam wujud obyek latar depan seperti lampu kapal, lampu mercusuar, lampu menara seluler, bentuk awan tertentu dan sebagainya maupun obyek latar belakang seperti Merkurius, Venus, Mars, Jupiter maupun bintang terang yang bisa nampak pada saat senja tepat saat sunset seperti Sirius. Lihat juga Djamaluddin, Reevaluation of Hilāl Visibility in Indonesia, 2000, h. 137.

${ }^{10}$ Sebagai contoh, laporan ru'yat 19 September 2009 (penentuan 1 Syawwal 1430 H) dari Cakung dan Basmol (keduanya di Jakarta), tidak diterima karena laporan bertentangan dengan kondisi langit Jakarta secara kuantitatif dan kualitatif yang pada saat bersamaan ternyata mendung, bahkan hujan.Demikian halnya laporan ru'yat 29 Agustus 2011 (penentuan 1 Syawwal 1432 H) dari Cakung dan Jepara (Jawa Tengah) yang juga ditolak karena faktor yang sama. Pun demikian laporan ru'yat 19 Juli 2012 (penentuan 1 Ramadhan $1433 \mathrm{H}$ ) dari Cakung.

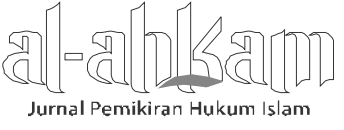


dan Zulhijjah) dan mayoritas kalangan Nahdlatul 'Ulama mulai bisa menerima "kriteria" yang digagas Kementerian Agama RI sebagai perangkat limitasi sekaligus sebagai basis penyusunan kalender Hijriyyahnya. Namun Nahdlatul 'Ulama tidak monolit sehingga selalu terdapat deviasi. ${ }^{11}$

Guna menjembatani hisāb dengan ru'yat dan khususnya guna menyatukan beda pendapat Muhammadiyah dan Nahdlatul 'Ulama, Kementerian Agama RI menggagas kriteria imkān ru'yat atau MABIMS (akronim Malaysia, Brunei Darussalam, Indonesia dan Singapura). Kriteria ini kemudian dinamakan kriteria imkān ru'yat 1998 yang menyatakan bahwa bulan diasumsikan berada dalam fase hilāl jika ketiga syarat berikut terpenuhi, yaitu: a) $h \geq 2^{\circ}$ atau $a_{D} \geq 3^{\circ}$, b) $a_{L} \geq 3^{\circ}$, dan c) umur bulan saat matahari terbenam $\geq 8$ jam setelah konjungsi. Kriteria ini menjadi basis penyusunan kalender Hijriyyah dan taqwim standar oleh Kementerian Agama RI dan sekaligus sebagai filter evaluasi laporan ru'yat melalui forum sidang ithbāt penentuan 1 Ramadhan, Syawwal dan Zulhijjah. "Kriteria" ini diberlakukan secara wilāyat al-ḥukm untuk Indonesia dan kawasan Asia Tenggara sehingga bersifat regional.

Namun kriteria imkān ru'yat 1998 kemudian dikritik sebagai kriteria yang tak memenuhi syarat ilmiah sehingga upaya perbaikan pun dilakukan. Misalnya dalam kriteria LAPAN 2000 yang toposentrik dan airless dengan bentuk: 12

$$
a_{D} \geq 0,14 D A z^{2}-1,83 D A z+9,11 \quad \text { *pers. (6) }
$$

Di sini bulan di Indonesia berada dalam fase hilāl jika memiliki $\mathrm{a}_{\mathrm{D}}$ minimum $3,12^{\circ}\left(\mathrm{DAz}=6,54^{\circ}\right)$ hingga maksimum $9,11^{\circ}\left(\mathrm{DAz}=0^{\circ}\right)$. Jika ketebalan atmosfer turut diperhitungkan, maka bagi dataran rendah hingga elevasi $30 \mathrm{~m}$ dari permukaan laut (dimana matahari terbenam terjadi jika $s=-1^{\circ}$ ) bulan berada dalam fase hilāl jika tingginya bervariasi antara $2,12^{\circ}$ hingga $8,11^{\circ}$. Perbaikan berikutnya melahirkan kriteria LAPAN 2009, dimana bulan diasumsikan berada dalam fase hilāl jika kedua syarat berikut terpenuhi,13 yaitu: a) $\mathrm{a}_{\mathrm{D}} \geq 4^{\circ}$, dan b) $\mathrm{a}_{\mathrm{L}} \geq$ $6,4^{\circ}$. Selanjutnya disusul dengan lahirnya "kriteria" imkān ru'yat $2011^{14}$ dimana

\footnotetext{
${ }^{11}$ Misalnya pada Tarīqah Naqshabandiyyah Padang (Sumbar), Țarīqah Naqshabandiyyah Khālidiyyah Jombang (Jatim), an-Nādzir Gowa (Sulsel) dan kadangkala Țarīqah Shattāriyyah Padang (Sumbar), yang kerap berbeda dengan keputusan PBNU.

${ }^{12}$ Djamaluddin, "Re-evaluation of Hiläl Visibility in Indonesia”, 2000, h. 138.

${ }^{13}$ Djamaluddin, “Astronomi Memberi Solusi Penyatuan Ummat”, Booklet LAPAN, 2011, h. 23.

${ }^{14}$ Kemenag RI, Keputusan Lokakarya Mencari Kriteria Format Awal Bulan di Indonesia, 2011, h. 42.

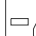

Jurnal Pemikiran Hukum Islam 
bulan diasumsikan berada dalam fase hilāl jika salah satu dari dua syarat berikut terpenuhi, yaitu: a) $h \geq 2,25^{\circ}\left(a_{D} \geq 3,25^{\circ}\right)$ dan umur bulan saat matahari terbenam $\geq 8$ jam setelah konjungsi, dan $b) h \geq 2,25^{\circ}\left(a_{D} \geq 3,25^{\circ}\right)$ dan $a_{L} \geq 3^{\circ}$.

Realitasnya, saat ini terdapat tiga kriteria berbeda tentang penetapan tanggal 1 Hijriyyah di Indonesia, khususnya tentang penetapan tanggal 1 Ramadhan, Syawwal dan Zulhijjah, yakni kriteria wujūd al-hilāl, kriteria imkān rưyat 2011, dan kriteria LAPAN 2009. Ketiganya memiliki bentuk berbeda dibandingkan kriteria visibilitas yang telah mapan (valid dan reliabel) dan jika menjumpai bulan dengan elemen kritikal maka implementasinya akan menghasilkan keputusan yang berbeda pula seperti yang terakhir dijumpai dalam penentuan 1 Zulhijjah $1431 \mathrm{H}$ (2010), 1 Syawwal 1432 H (2011) dan 1 Ramadhan 1433 H (2012). Eksistensi ketiga kriteria tersebut menunjukkan adanya pergeseran paradigma dalam mendefinisikan hilāl dari yang semula berupa hilāl empirik ${ }^{15}$ menjadi hilāl asumtif. ${ }^{16}$ Ketiga kriteria itu sebagian atau sepenuhnya berlandaskan pada asumsi tanpa ditunjang data observasi.

Kriteria wujūd al-hilāl, sampai saat ini belum memiliki data observasi hilāl yang valid dan reliabel yang menyatakan pada elemen kritikal wujūd al-hilāl di mana hilāl sudah teramati. Yang ada justru data observasi lengkungan sabit bulan tepat saat konjungsi seperti misalnya dilaporkan Legault pada 14 April 2010 TU. Observasi tersebut dilakukan dengan teknik khusus dan memiliki tingkat kesulitan sangat tinggi. Lengkungan sabit bulan yang membentuk busur sepanjang $70^{\circ}$ baru diperoleh setelah Legault memotret bagian langit dimana hisāb memperkirakan bulan berada dengan menggunakan teleskop yang dilengkapi penapis cahaya (guna memblokir sinar matahari) dan video dengan filter inframerah $850 \mathrm{~nm}$ (8.500 Angstrom). ${ }^{17}$ Citra lengkungan sabit bulan muncul setelah 500 citra terpisah yang telah dikalibrasi digabungkan menjadi satu dengan teknik stacking. Analisa fotometrik memperlihatkan jika dipotret secara biasa saja (tanpa pengolahan citra dan stacking), sabit bulan tidak akan terlihat sama sekali mengingat

\footnotetext{
${ }^{15}$ Hilāl empirik adalah istilah penulis bagi hilāl definitif yang didukung oleh data observasi dan ditunjang model matematis terkini pada zamannya. Secara singkat hilāl empirik merupakan "hilāl yang benar."

${ }^{16} \mathrm{Hilāl}$ asumtif adalah istilah penulis bagi hilāl definitif yang yang hanya mendasarkan hilāl pada asumsi/hipotesis tertentu menurut hisāb atau ru'yat. Secara singkat hilāl asumtif merupakan "hilāl yang tidak benar."

${ }^{17}$ Legault, "World Record: The Youngest New Moon Crescent", April 14, 2000. Astrosurf, http://astrosurf.com/legault/new_moon_2010april14.html, diunduh pada 20 April 2010.
} 
cahaya langit empat ratus kali lebih terang dibanding sabit bulan dalam spektrum cahaya inframerah. Bahkan dalam spektrum cahaya tampak langit seribu kali lipat lebih terang. Keberhasilan observasi ini juga ditunjang oleh posisi bulan di langit setempat, yang pada waktu konjungsi (14 April 2010 pukul 13:30 waktu Eropa) terletak di ketinggian $53^{\circ}$. Sebaliknya observasi dengan teknik serupa gagal mendeteksi lengkungan sabit bulan ketika matahari terbenam. Dengan kekhususan tekniknya, sulit untuk mengatakan citra lengkungan sabit bulan ini sebagai hilāl.

Demikian halnya kriteria imkān ru'yat 2011. Kriteria ini semula berbasis laporan ru'yat 29 Juni 1984 (penentuan 1 Syawwal 1404 H) dimana hilāl dilaporkan terlihat di Jakarta, Pelabuhan Ratu (Jawa Barat) dan Pare-Pare (Sulawesi Selatan) dengan $\mathrm{h} \approx 2^{\circ}$. Nilai inilah yang digunakan untuk membangun asumsi bahwa hilāl berpotensi terlihat (imkān ru'yat) ketika tinggi minimal bulan $2^{\circ}$ secara homogen (tanpa mempedulikan DAz) saat matahari terbenam pasca konjungsi. Namun meski berasal dari tiga titik observasi berbeda dan berjauhan, laporan ini mengundang kontroversi mengingat pada 29 Juni 1984 senja di langit barat juga terdapat Venus dan Merkurius dalam posisi berdekatan dengan bulan. Kedua benda langit ini berpotensi teramati sebagai hilāl palsu yang mengecoh. Analisa fotometrik berbasis teorema Sultan memperlihatkan hasil sebagai berikut: ${ }^{18}$

Tabel 1.

Parameter Fisik dan Fotometrik Bulan dan Venus untuk 29 Juni 1984 di Jakarta saat Matahari Terbenam

\begin{tabular}{lcc}
\hline \multicolumn{1}{c}{ Deskripsi } & Bulan & Venus \\
\hline Tinggi & $2,75^{\circ}$ & $3,5^{\circ}$ \\
Azimuth & $296,5^{\circ}$ & $294,2^{\circ}$ \\
Fase & $0,14 \%$ & $99,78 \%$ \\
Diameter nampak (apparent) & $0,5^{\circ}$ & $0,0027^{\circ}$ \\
Intensitas cahaya & $3,6.10^{8}$ nanolambert & $4,2.10^{9}$ nanolambert \\
Nilai kontras & 6 & 74 \\
Nilai kontras langit senja & 110 & 11 \\
\hline
\end{tabular}

${ }^{18}$ Sultan, "Hijri Calendar \& Lunar Visibility: Physical Approach", The 3rd Islamic Astronomical Conference, Astronomical Applications in Islamic Shari'a. Amman, Oct 20th - 22nd, 2003, h. 3.

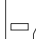

Jurnal Pemikiran Hukum Islam 
Meskipun diameter nampak Venus jauh lebih kecil dibanding bulan, namun fasenya jauh lebih besar sehingga intensitas cahaya Venus yang tiba di permukaan bumi adalah 11,6 kali lipat lebih besar dibanding intensitas cahaya bulan. Dalam fotometri, sebuah benda langit akan terlihat mata jika nilai kontrasnya lebih besar dibanding nilai kontras langit di latar belakangnya. ${ }^{19}$ Dengan nilai kontras Venus lebih besar dibanding langit senja dan sebaliknya nilai kontras bulan lebih kecil dibanding langit senja, maka Venus dapat dilihat dan sebaliknya bulan tidak. Ketidaktahuan pengamat membuat Venus disangka sebagai hilāl.

Adanya data meragukan, "kriteria" imkān ru'yat (khususnya imkān ru'yat 1998) tidak punya dasar yang bisa dipertanggungjawabkan secara ilmiah sehingga hanyalah sekedar asumsi. Walaupun sejak awal dinyatakan sebagai "kriteria sementara" yang berlaku hingga kelak terdapat data-data observasi yang valid dan reliabel untuk mendukung atau merevisinya, dalam perkembangannya tidak ada upaya dari para pihak terkait untuk menyelenggarakan praktik observasi berkelanjutan yang metodis guna mengakuisisi data observasi tersebut. Meski dilakukan revisi pada 2011 (yang melahirkan "kriteria" imkān ru'yat 2011), revisi tersebut pada galibnya lebih menekankan kompromi di antara para pihak pasca keriuhan dalam Idul Fitri $1432 \mathrm{H}$, tanpa berupaya meninjaunya lebih mendalam dengan data observasi terkini yang valid dan reliabel. Perkembangan terakhir menunjukkan kriteria yang semula diniatkan sebagai kriteria pemersatu sekaligus kriteria regional ini kurang dipatuhi baik di tingkat Asia Tenggara ${ }^{20}$ maupun dalam negeri. ${ }^{21}$

Kriteria LAPAN 2009, semula disusun sebagai kriteria LAPAN 2000 yang berdasarkan pada 38 laporan ru'yat yang dihimpun Kementerian Agama RI selama 30 tahun (1967-1997). Setelah terjadi reduksi data, maka tinggal tersisa 11 data yang dianggap valid..$^{22}$ Tiga dari delapan data diantaranya dianggap meragukan

\footnotetext{
${ }^{19}$ Arumaningtyas, "Studi Kecerlangan Langit terhadap Visibilitas Hilāl", Skripsi, tidak diterbitkan: Program Studi Astronomi F-MIPA ITB, Bandung, 2009, h. 45.

${ }^{20}$ Brunei Darussalam merayakan Idul Fitri dan Idul Adha $1430 \mathrm{H}$ pada hari yang berbeda dibanding Indonesia, Singapura dan Malaysia. Demikian halnya pada Idul Fitri 1432 H, Indonesia dan Malaysia merayakannya pada hari yang berbeda.

${ }^{21}$ Muhammadiyah menganggap "kriteria" Imkan Rukyat tidak ilmiah karena tidak didasarkan pada bukti yang kuat, meski apabila ditelaah lebih lanjut, wujudul hilāl yang digunakan Muhammadiyah pun ternyata tidak ilmiah. Lihat Djamaluddin, Re-evaluation of Hiläl Visibility in Indonesia, 2000, h. 137.

${ }^{22}$ Reduksi datanya melalui 2 tahap. Pertama, apabila aD $<4^{\circ}$ maka laporan bisa diterima jika berasal dari minimal 3 titik observasi yang berbeda dan tidak saling berdekatan. Reduksi ini
} 
sehingga hanya tersisa 8 data yang benar-benar valid. Jumlah data yang terlalu kecil menyebabkan kriteria LAPAN 2000 berpotensi bias. Masalah keterbatasan data belum teratasi ketika muncul perbaikan yang melahirkan kriteria LAPAN 2009, dimana kriteria terakhir ini juga bersifat asumtif. Meski berdasarkan analisis Ilyas (1988) dan Audah (2004), postulat-postulat dalam kriteria LAPAN 2009 belum pernah diuji di Indonesia.

Kualitas data observasi hilāl memang telah lama menjadi keprihatinan astronom Muslim kontemporer dan ini tidak terjadi di Indonesia saja, namun telah menjadi masalah klasik negara-negara Islam atau negara berpenduduk mayoritas Islam lainnya hingga saat ini. Misalnya Saudi Arabia, dari 46 data observasi positif ${ }^{23}$ pada periode 1961-2004 TU hanya 6 (13\%) saja yang dinyatakan valid. Demikian pula dari 112 data observasi positif di Yordania pada periode 1954-2007 TU hanya 9 (8\%) yang valid. Algeria sedikit lebih baik, karena dari 115 data observasi positif yang dihimpun selama periode 1963-2000 TU, 95 (82,6\%) diantaranya dinyatakan valid.

Selain masalah kualitas data, Indonesia pada khususnya dan daerah tropis pada umumnya juga mempunyai masalah lain, yaitu terlalu sedikitnya jumlah data yang valid dan reliabel. Sebagai pembanding terhadap data Kementerian Agama RI di atas, PRTI (Penserasian Rukyah dan Takwim Islam) hanya mempunyai 38 data observasi positif untuk kurun waktu yang hampir sama. Demikian juga pada basis data ICOP, dari 737 data hanya 51 (6,9\%) yang berasal dari kawasan tropis. Sedangkan dalam basis data Yallop, dari 295 data hanya 28 (9,5\%) yang berasal dari kawasan tropis.

Kecilnya jumlah data dan adanya perbedaan bentuk kriteria imkān ru'yat (baik versi 1998 maupun revisi 2011) dengan kriteria visibilitas yang mapan serta didorong harapan menyatukan kalender Hijriyyah di Indonesia menjadi faktor penggerak Lembaga Pengkajian dan Pengembangan Ilmu Falak Rukyatul Hilāl Indonesia (LP2IF RHI) melaksanakan kampanye observasi hilāl dan hilāl tua secara menerus sejak Zulhijjah 1427 H (Januari 2007 TU). Observasi menerus ini bertujuan menciptakan Basis Data Visibilitas Indonesia yang mencakup data visibilitas bulan sebagai hilāl dan hilāl tua di Indonesia, baik observasi positif maupun negatif. Basis

membuat hanya 15 laporan yang lolos dari 38 laporan. Dan yang kedua, laporan yang lolos bisa diterima jika tidak berdekatan dengan Merkurius dan Venus. Akibatnya hanya 11 yang lolos dari 15 laporan tersisa. Lebih lengkap lihat Djamaluddin, Re-evaluation of Hilāl Visibility in Indonesia, 2000, h.138.

${ }^{23}$ Data observasi positif: data yang menyatakan terlihatnya bulan sebagai hilāl.

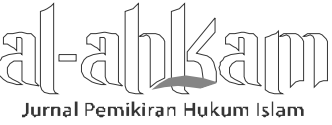


data ini selanjutnya bisa dianalisis dan dibandingkan dengan teori visibilitas mapan untuk mengetahui variasi lokal yang mungkin terjadi terkait kekhasan letak Indonesia sehingga dapat dirumuskan definisi hilāl secara kuantitatif baik dalam skala nasional (Indonesia) maupun regional (Asia Tenggara).

Metode yang digunakan adalah dengan observasi terus-menerus pada setiap pergantian bulan Hijriyyah dan tak terbatas pada Ramadhan, Syawwal dan Zulhijah semata. Target obyektif observasi adalah bulan dalam fase hilāl dan hilāl tua. Adapun partisipan dalam penelitian ini adalah sejumlah praktisi ilmu falak, anggota Badan Hisab dan Rukyat (BHR) setempat, personalia LFNU setempat, anggota klub astronomi, pegawai Kementerian Agama, pesantren dan staf institusi ilmiah yang secara sukarela membentuk jejaring RHI.

Belasan titik observasi yang merentang dari garis lintang $5^{\circ} \mathrm{LU}$ (Lhokseumawe, Aceh) hingga $32^{\circ}$ LS (Reabold Hill, Perth, Australia Barat) serta dari garis bujur $97^{\circ}$ BT (Lhokseumawe, Aceh) hingga bujur $112,5^{\circ}$ BT (Condrodipo, Gresik, Jawa Timur) menjadi lokasi observasi. Data observasi dari pengamat yang tidak tergabung dalam jejaring tersebut tetap diterima, namun harus memenuhi persyaratan sebagai berikut: a) ada catatan tentang selisih waktu antara terbenamnya matahari dengan terbenamnya bulan (Lag), b) ada catatan orientasi/kemiringan hilāl, c) ada catatan kondisi horizon dan langit di atasnya, d) ada catatan alat bantu optik yang digunakan, dan e) ada citra/foto hilāl. Persyaratan itu dibuat agar laporan bisa disesuaikan dengan prosedur standar pengamatan dalam jejaring RHI.

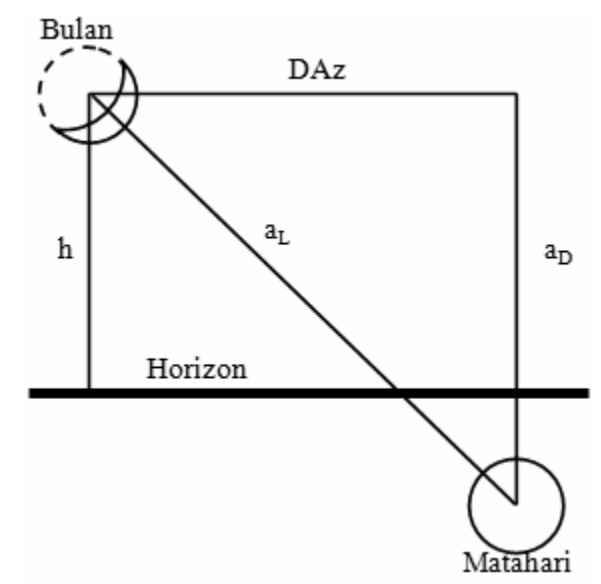

Gambar 1.

Geometri Dasar Elemen-elemen Posisi Bulan dan Matahari untuk Menyusun Basis Data Visibilitas Indonesia

122 Volume 24, Nomor 1, April 2014

Jurnal Pemikiran Hukum Islam 
Data observasi diolah dengan algoritma Jean Meeus menggunakan software Moon Calculator v6.0 dengan setting yang disarankan Audah, yakni pada kondisi toposentrik, airless dan terbit/terbenamnya matahari secara geometrik. Keluarannya berupa: $a_{D}, h, a_{L}, D A z$, umur bulan, Lag, Mag, W dan R. Khusus untuk $a_{D}, D A z$ dan $a_{L}$, ketiganya membentukgeometri sebagaimana dinyatakan dalam gambar 1 di atas.

Hasil analisa kemudian diklasifikasikan kembali dalam data observasi positif dan negatif. ${ }^{24}$ Data selanjutnya mengalami reduksi dengan membandingkan kondisi langit lokal secara kualitatif, baik berdasarkan laporan pengamat ataupun citra satelit spektrum visual. ${ }^{25}$ Jika kondisi langit tidak memungkinkan matahari terlihat sejak sejam sebelum terbenam, maka data observasi positif maupun negatif akan dieliminasi. Hingga Desember 2009 TU (Zulhijjah 1430 H) kampanye observasi telah menghasilkan 107 data observasi positif dan 67 data observasi negatif. Sehingga secara akumulatif terhimpun 174 data. Data ditabulasikan secara terpisah antara yang positif dan negatif, kemudian dianalisis dengan metode leastsquare dibantu spreadsheet Microsoft Excell tanpa dibedakan apakah visibilitas tersebut terjadi dengan mata tanpa ataukah dengan alat bantu optik. Seluruh data ini kemudian dinamakan Basis Data Visibilitas Indonesia (BDVI).

\section{Visibilitas Hilāl dan Kriteria Visibilitas Klasik}

Observasi hilāl tercatat telah dilakukan sejak abad ke-5 STU oleh astronom kuno Babilonia yang dilaksanakan saat matahari terbenam dalam waktu tertentu tanpa bantuan alat optik. Tabel-tabel tanah liat (cuneiform) yang telah diekskavasi memperlihatkan observasi hilāl berlangsung secara terus-menerus selama lima abad (568-74 STU). ${ }^{26}$ Data observasi yang berhasil diakumulasikan selama itu memungkinkan mengkonstruksi kriteria visibilitas hilāl, yakni batas minimum prediktif yang valid dan reliabel bagi bulan sebagai hilāl untuk mata dalam kondisi diidealkan sekaligus sebagai jembatan penghubung antara hisāb dan ru'yat. Rekonstruksi modern terhadap data-data Babilonia menghasilkan kriteria visibilitas

\footnotetext{
${ }^{24}$ Untuk data observasi positif, pengolahan data dilakukan pada saat best time aktual seperti disarankan Audah. Sementara pengolahan data observasi negatif berdasarkan waktu terbenam matahari (pada hilāl) dan terbitnya matahari (pada hilāl tua).

${ }^{25}$ Citra satelit yang digunakan merujuk pada http://weather.is.kochi-u.ac.jp/SE/ diunduh 10 Juni 2012.

26Fatoohi et.al., The Danjon Limit of First Visibility of The Lunar Crescent, Volume 118 (t.tp: The Observatory, 1998), h. 69.
} 
klasik generasi pertama yang dinamakan kriteria Babilon. ${ }^{27}$ Kriteria ini berbentuk sangat sederhana. Bulan berada dalam fase hilāl jika antara bulan dan matahari memiliki as $\geq 12^{\circ}$. Dengan Babilonia terletak di Lembah Mesopotamia (lintang $23^{\circ}$ LU), kriteria tersebut bisa diterjemahkan sebagai Lag $\geq 48$ menit. Secara terpisah hal serupa juga dijumpai dalam peradaban India meski mereka hidup pada masa lebih kemudian yakni abad ke-6 TU. Selama 25 abad kemudian kriteria visibilitas terus dikembangkan, yang secara garis besar terbagi ke dalam kriteria visibilitas empiris $^{28}$ dan kriteria visibilitas fisis. ${ }^{29}$

Seiring kian berkembangnya peradaban, cendekiawan Muslim mulai membakukan tradisi mengobservasi hilāl dan berinovasi dalam menyusun kriteria visibilitas empiris yang secara garis besar terbagi dalam dua kelompok. Kelompok pertama menekankan visibilitas hilāl sebagai fungsi aL. Al-Khwārizmī (w. 830 TU) menjadi pelopornya dengan merumuskan hilāl sebagai bulan yang memiliki $\mathrm{a}_{\mathrm{L}}>$ 9,5․ Ibn Maymūn (731-861 TU) mengikuti langkah al-Khwārizmī sembari memperhitungkan musim semi dan musim gugur sebagai variabelnya di samping memperkenalkan besaran a, sehingga hilāl menurut Ibn Maymūn merupakan bulan yang memiliki $9^{\circ} \leq \mathrm{a}_{\mathrm{L}} \leq 24^{\circ}$ dan $\mathrm{a}_{\mathrm{D}}+\mathrm{a}_{\mathrm{L}} \geq 22^{\circ}$. Ibn Qurrā (826-901 TU) membentuk ulang kriteria ibn Maymūn menjadi $11^{\circ} \leq \mathrm{a}_{\mathrm{L}} \leq 25^{\circ}$. Sementara kelompok kedua menekankan visibilitas hilāl merujuk pada kriteria Babilon sebagai bentuk dasar. As-Sūfì (w. 986 TU), Ibn Sīnā, aṭ-Ṭūsī (1258-1274 TU), dan al-Kashānī (abad ke-15 TU) menggunakan bentuk asli kriteria Babilon. Sementara al-Battānī (850-929 M) dan al-Farghānī sedikit berinovasi dengan merumuskan hilāl adalah bulan yang memiliki $\mathrm{as}_{\mathrm{s}}<12^{\circ}$ namun khusus untuk $\mathrm{a}_{\mathrm{L}}$ besar.

Meski demikian terdapat perkecualian juga. Al-Birūnī misalnya, turut mengembangkan kriteria visibilitas empiris sebagai fungsi $a_{D}$ dan DAz. Ia juga mengembangkan sistem hisāb 'urfi, yakni sistem perhitungan kalender sederhana yang menetapkan umur bulan secara pasti (Muharram = 30 hari, Șafar = 29 hari, Rabỉ' al-Awwal = 30 hari dan seterusnya) dalam setahun Hijriyyah dan mencakup sistem isțilạhī, dimana dalam 30 tahun Hijriyyah terdapat 11 tahun kabisat (berumur

\footnotetext{
${ }^{27}$ Ibid, h. 70. Baca juga: Ilyas, Lunar Crescent Visibility Criterion and Islamic Calendar. Q. J. R. Astronomical Society, 425-461, 1994, h. 430.

${ }^{28}$ Adalah kriteria visibilitas yang berdasarkan pada elemen posisi bulan dan matahari seperti aD, $h$, DAz, aL dan lain-lain.

${ }^{29}$ Adalah kriteria visibilitas yang berdasarkan pada sifat fisik bulan seperti fase, magnitude, W, kontras dan lain-lain.
}

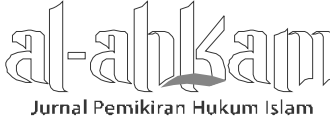


355 hari) sementara sisanya adalah tahun biasa (berumur 354 hari). Sistem hisāb 'urfi digunakan untuk menyusun kalender sepanjang tahun Hijriyyah meski penentuan awal lunasi tetap berdasarkan kriteria visibilitas.

\section{Kriteria Visibilitas Modern}

Setelah mengalami stagnasi sepanjang abad ke-15 hingga 18 TU, riset tentang hilāl memasuki babak baru seiring upaya Schmidt di Athena (Yunani) melaksanakan observasi hilāl. Selama 20 tahun (1859-1877 TU) Schmidt menghasilkan 72 data visibilitas positif. Fotheringham (1910) memanfaatkannya guna membangun kriteria visibilitas berbasis DAz dan aD mengikuti langkah al-Battānī berabad sebelumnya.30 Maunder (1911) memperbaiki model Fotheringham dengan menambahkan data observasi baru serta melakukan koreksi data Schmidt sehingga terbentuk kriteria Fotheringham-Maunder dengan bentuk:

$$
a_{D} \geq-0,01 D A z^{2}-0,05 D A z+11
$$

Kriteria ini adalah tonggak kriteria visibilitas modern meskipun hingga delapan dekade kemudian tidak benar-benar direalisasikan guna penyusunan kalender Hijriyyah ${ }^{31}$. Untuk DAz $=0^{\circ}$ diperoleh $\mathrm{a}_{\mathrm{D}} \geq 11^{\circ}$ yang setara dengan as $\geq$ $12^{\circ}$ bagi garis lintang $23^{\circ} \mathrm{LU}$ yang membuat kriteria ini telah mencakup kriteria Babilon. Sehingga pada dasarnya kriteria Fotheringham-Maunder bisa diaplikasikan untuk kawasan yang lebih luas (kriteria regional) dan tidak terbatas dalam lingkup tertentu saja (kriteria lokal) sebagaimana halnya kriteria Babilon.

Riset hilāl memasuki ranah baru kala F. Bruin (1977) memperkenalkan metode teoritis modern guna menyusun kriteria visibilitas fisis yang mengandung variabel $W$ dan $a_{D}$ mengikuti langkah al-Biruni berabad sebelumnya. Kriteria baru ini dinamakan kriteria Bruin. Khusus untuk DAz $<20^{\circ}$, kriteria Bruin dapat ditransformasikan menjadi:

$$
a_{D} \geq-0,03 D A z^{2}+0,14 D A z+10,136 \quad \text { *pers. (2) }
$$

Meski disadari tidaklah sempurna dan mengandung banyak kekurangan, kriteria Bruin menjadi basis bagi pengembangan kriteria-kriteria visibilitas modern berikutnya.

30Moh. Ilyas, Lunar Crescent Visibility Criterion and Islamic Calendar, 1994, h. 436.

31Zainal, A Selective Literature Review of Young Moon Crescent Visibility Studies, ICOP http://icoproject.org/ diunduh pada 30 Januari 2008, h. 3.

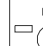

Jurnal Pemikiran Hukum Islam 
Moh. Ilyas mengembangkan kriteria Bruin dengan merevisi nilai W dari semula 0,5 menjadi 0,25. Ilyas menemukan jika perubahan tersebut diterapkan maka $\mathrm{a}_{\mathrm{L}}$ minimum kriteria Bruin akan bersesuaian dengan $\mathrm{a}_{\mathrm{L}}$ minimum kriteria Fotheringham-Maunder, yakni $11^{\circ}$. Pengembangan Ilyas ini membuat kriteria Fotheringham-Maunder bisa diaplikasikan bagi kawasan yang lebih luas lagi dibanding sebelumnya sehingga mencakup daerah lintang tinggi (kriteria global). Pengembangan ini melahirkan kriteria baru yang disebut Kriteria Komposit Ilyas. ${ }^{32}$

Ilyas juga memperkenalkan konsep Garis Tanggal Kalender Lunar Internasional (International Lunar Date Line/ILDL), yang bentuknya sangat berbeda dibanding Garis Tanggal Internasional (International Date Line/IDL) dalam kalender Shamsiyyah. Jika Garis Tanggal Internasional memiliki posisi tetap dan membujur mengikuti garis tertentu (yakni garis bujur $180^{\circ}$ ) sembari menyesuaikan diri dengan batas-batas politis wilayah administratif yang dilintasinya, maka Garis Tanggal Kalender Lunar Internasional berposisi melintang (tanpa merujuk garis bujur maupun lintang tertentu) dan senantiasa berpindah-pindah dari satu bulan ke bulan Hijriyyah lainnya.
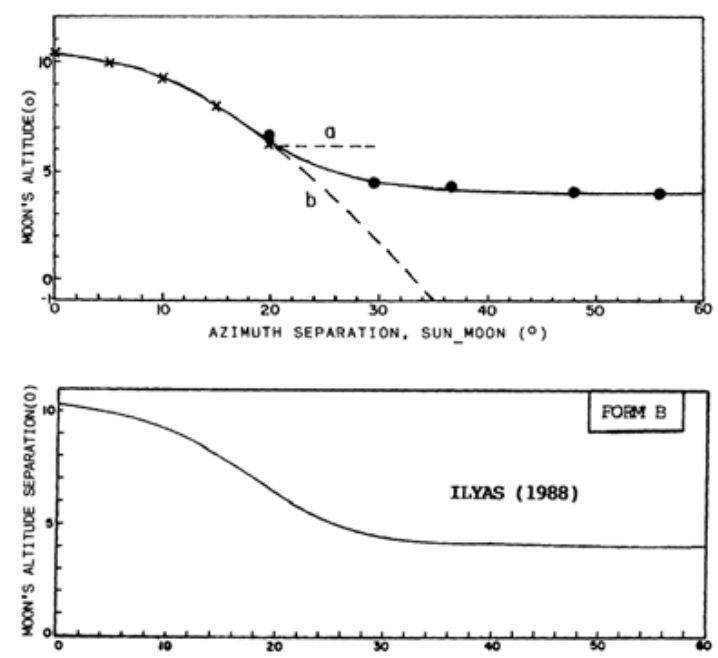

Gambar 2.

Dua Contoh Kurva Kriteria Visibilitas Modern, yakni Fotheringham-Maunder (atas) dan Komposit Ilyas (bawah). (Sumber: Ilyas, 1994)

32Moh. Ilyas, Lunar Crescent Visibility Criterion, h. 5. 
Pengembangan termutakhir dilakukan Yallop (1997) dan Audah (2004). Menggunakan 295 data observasi dari Bradley Scahefer (AS), Yallop membentuk ulang kriteria Bruin menjadi kriteria Yallop,33 yang selangkah lebih maju karena telah menggunakan kondisi toposentrik walau terbatas hanya untuk variabel W'. Sementara Audah menyusun kriterianya dengan berdasarkan data berlimpah, yakni 737 data observasi yang terdiri dari: 294 data observasi Bradley Schaefer (AS), 6 data observasi Jim Stamm (AS), 42 data observasi SAAO (South African Astronomy Observatory), 15 data observasi Mohsen Mirsaid (Iran), 57 data observasi Alireza Mehrani (Iran), dan 323 data observasi ICOP (Islamic Crescent Observation Project) sejak 1998.

Analisis 737 data observasi itu menghasilkan kriteria Audah (Odeh), yang pada dasarnya adalah perbaikan dari kriteria Yallop yang disusun secara toposentrik (variabel $a_{D}$ dan $\mathrm{W}$ ) dan airless. $^{34}$

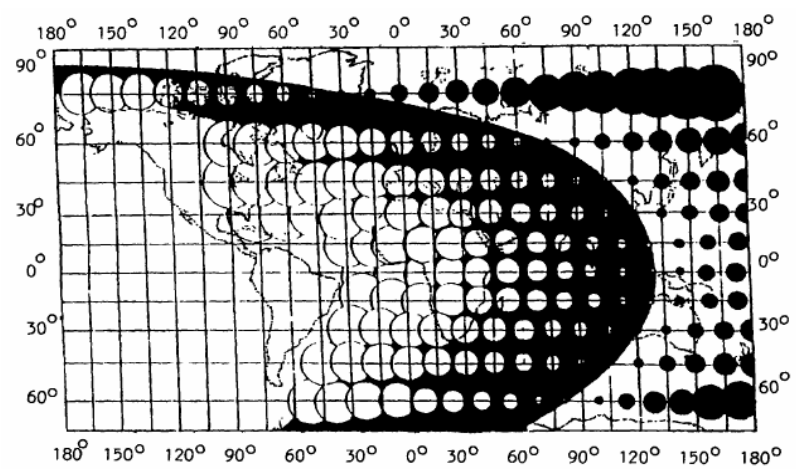

Gambar 3.

\section{Konsep Awal ILDL Menurut Ilyas (1979) 35}

Selain sifat toposentriknya, perbedaan kriteria Yallop dan Audah dibandingkan kriteria-kriteria visibilitas era sebelumnya terletak pada adanya parameter

\footnotetext{
33Yallop, "A Method for Predicting the First Sighting of The New Crescent Moon", NAO Technical Note No. 69, 1997, h. 3. 43.

${ }^{34}$ Audah, "New Criterion for Lunar Crescent Visibility", Experimental Astronomy, Volume 18, 2004, h.

${ }^{35}$ Konsep awal ILDL Menurut Ilyas (1979)sebagai lengkungan berwarna hitam. Pada suatu garis lintang tertentu, peluang visibilitas hilāl semakin besar jika semakin ke barat dari posisi ILDL (diperlihatkan oleh kian membesarnya lingkaran putih) dan sebaliknya kian mengecil jika semakin ke timur dari ILDL (diperlihatkan oleh kian membesarnya lingkaran hitam). (Sumber: Ilyas, 1994)
}

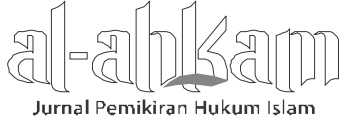


tertentu untuk mengklasifikasi sifat visibilitas. Dengan kriteria Yallop memiliki bentuk:

$$
10 q=a_{D}-\left(-0,1018 W^{\prime 3}+0,7319 W^{\prime 2}-6,3226 W^{\prime}+11,8371\right) * \text { pers. (3) }
$$

dan kriteria Audah berbentuk:

$$
V=a_{D}-\left(-0,1018 W^{3}+0,7319 W^{2}-6,3226 W+7,1651\right) \quad * \text { pers.(4) }
$$

maka terdapat parameter q (Yallop) dan V (Audah) guna mengklasifikasikan sifat visibilitas hilāl dalam kondisi best time dengan formula:

$$
T_{b}=T_{s}+\frac{4}{9} \operatorname{Lag} \quad \text { *pers. (5) }
$$

Tabel 2.

Parameter q dan V

\begin{tabular}{lcc}
\hline \multicolumn{1}{c}{ Sifat Visibilitas } & q & V \\
\hline $\begin{array}{l}\text { Terlihat dengan mudah meski tanpa alat } \\
\text { bantu optik }\left(\mathrm{a} \mathrm{L} \geq 12^{\circ}\right)\end{array}$ & $\mathrm{q}>0,216$ & $\mathrm{~V} \geq 5,65$ \\
$\begin{array}{l}\text { Terlihat tanpa alat bantu optik namun } \\
\text { mungkin juga terlihat tanpa alat bantu }\end{array}$ & $-0,014<\mathrm{q} \leq 0,216$ & $2,00 \leq \mathrm{V}<5,65$ \\
optik dalam kondisi langit sempurna & & \\
Hanya terlihat dengan alat bantu optik & $-0,232<\mathrm{q} \leq-0,014$ & $-0,96 \leq \mathrm{V}<2,00$ \\
Tak terlihat & $\mathrm{q} \leq-0,232$ & $\mathrm{~V}<-0,96$ \\
\hline
\end{tabular}

\section{Kriteria Visibilitas Indonesia}

Analisis terhadap Basis Data Visibilitas Indonesia berhasil merumuskan kriteria visibilitas baru untuk Indonesia, dengan mengikuti model matematis yang pertama kali disarankan al-Battānī yakni menggunakan variabel $a_{D}$ dan DAz. Perbandingan nilai minimum $a_{D}$ terhadap beragam nilai DAz menghasilkan sebuah pertidaksamaan polinomial dengan bentuk:

$$
a_{D} \geq 0,099 D A z^{2}-1,490 D A z+10,382 \quad \text { *pers. (7) }
$$

Apabila diuraikan lebih lanjut maka pertidaksamaan itu dapat dituliskan sebagai berikut:

128 Volume 24, Nomor 1, April 2014 
Tabel 3.

a Minimum terhadap DAz bagi Kriteria Visibilitas Indonesia

\begin{tabular}{cccccccc}
\hline $\mathbf{D A z}\left(\mathbf{(}^{\circ}\right)$ & ad $\left(\mathbf{(}^{\circ}\right)$ & $\mathbf{D A z}\left(\mathbf{(}^{\circ}\right)$ & ad $\left({ }^{\circ}\right)$ & $\mathbf{D A z}\left(\mathbf{(}^{\circ}\right)$ & ad $\left({ }^{\circ}\right)$ & $\mathbf{D A z}\left(\mathbf{(}^{\circ}\right)$ & ad $\left(\mathbf{(}^{\circ}\right)$ \\
\hline 0 & 10,382 & 2,5 & 7,276 & 5 & 5,407 & 7,5 & 4,776 \\
0,25 & 10,016 & 2,75 & 7,033 & 5,25 & 5,288 & 7,75 & 4,781 \\
0,5 & 9,662 & 3 & 6,803 & 5,5 & 5,182 & 8 & 4,798 \\
0,75 & 9,320 & 3,25 & 6,585 & 5,75 & 5,088 & 8,25 & 4,828 \\
1 & 8,991 & 3,5 & 6,380 & 6 & 5,006 & 8,5 & 4,870 \\
1,25 & 8,674 & 3,75 & 6,187 & 6,25 & 4,937 & 8,75 & 4,924 \\
1,5 & 8,370 & 4 & 6,006 & 6,5 & 4,880 & 9 & 4,991 \\
1,75 & 8,078 & 4,25 & 5,838 & 6,75 & 4,835 & 9,25 & 5,070 \\
2 & 7,798 & 4,5 & 5,682 & 7 & 4,803 & 9,5 & 5,162 \\
2,25 & 7,531 & 4,75 & 5,538 & 7,25 & 4,783 & 9,75 & 5,266 \\
\hline
\end{tabular}

Nilai-nilai $\mathrm{a}_{\mathrm{D}}$ minimum dalam tabel 3 di atas, meski dalam perspektif toposentrik namun mengabaikan pembiasan atmosfer bumi (airless). Jika eksistensi atmosfer bumi diperhitungkan, maka akan diperoleh hasil sebagai berikut:

Tabel 4.

Nilai h Minimum terhadap DAz bagi Kriteria Visibilitas Indonesia pada Elevasi Nol Meter Dpl

\begin{tabular}{cccccccc}
\hline $\mathbf{D A z}\left(\mathbf{(}^{\circ}\right)$ & $\mathbf{h}\left(\mathbf{(}^{\circ}\right)$ & $\mathbf{D A z}\left(\mathbf{(}^{\circ}\right)$ & $\mathbf{h}\left({ }^{\circ}\right)$ & $\mathbf{D A z}\left({ }^{\circ}\right)$ & $\mathbf{h}\left({ }^{\circ}\right)$ & $\mathbf{D A z}\left(\mathbf{(}^{\circ}\right)$ & $\mathbf{h}\left({ }^{\circ}\right)$ \\
\hline 0 & 9,807 & 2,5 & 6,701 & 5 & 4,832 & 7,5 & 4,201 \\
0,25 & 9,441 & 2,75 & 6,458 & 5,25 & 4,713 & 7,75 & 4,206 \\
0,5 & 9,087 & 3 & 6,228 & 5,5 & 4,607 & 8 & 4,223 \\
0,75 & 8,745 & 3,25 & 6,01 & 5,75 & 4,513 & 8,25 & 4,253 \\
1 & 8,416 & 3,5 & 5,805 & 6 & 4,431 & 8,5 & 4,295 \\
1,25 & 8,099 & 3,75 & 5,612 & 6,25 & 4,362 & 8,75 & 4,349 \\
1,5 & 7,795 & 4 & 5,431 & 6,5 & 4,305 & 9 & 4,416 \\
1,75 & 7,503 & 4,25 & 5,263 & 6,75 & 4,26 & 9,25 & 4,495 \\
2 & 7,223 & 4,5 & 5,107 & 7 & 4,228 & 9,5 & 4,587 \\
2,25 & 6,956 & 4,75 & 4,963 & 7,25 & 4,208 & 9,75 & 4,691 \\
\hline
\end{tabular}

Dari tabel 4 dan tabel 5 di atas terlihat jelas bahwa agar bulan bisa disebut sebagai hilāl, ia harus memiliki h minimum yang bervariasi nilainya tergantung kepada DAz. Nilai minimum terkecil terjadi pada DAz 7,525 $\left(\mathrm{h}=4,201^{\circ}\right)$ 
sementara nilai minimum terbesar terjadi pada DAz $0^{\circ}$ atau saat bulan tepat ada di atas matahari kala matahari terbenam $\left(\mathrm{h}=9,807^{\circ}\right)$.

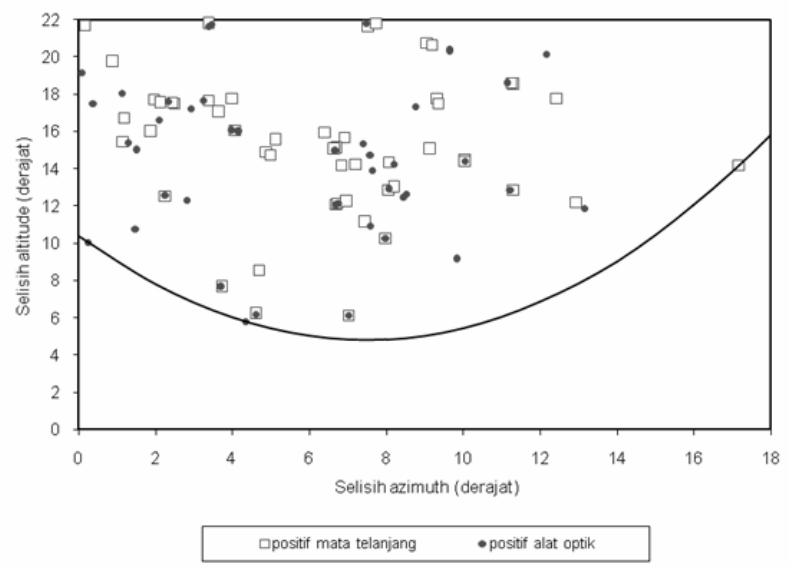

Gambar 4.

\section{Plotting Data Observasi Positif dalam Basis Data Visibilitas Indonesia menurut Variabel ap dan DAz. Garis Parabolik adalah Kurva Kriteria Visibilitas Indonesia (Kriteria RHI).}

Pertidaksamaan matematis: $a_{D} \geq 0,099 D A z^{2}-1,490 D A z+10,382$ untuk sementara disebut kriteria visibilitas Indonesia (kriteria RHI). Kriteria ini merupakan kurva yang membatasi dua kawasan yang berbeda, yakni kawasan dimana lengkungan sabit bulan tak terlihat di satu sisi dengan lengkungan sabit bulan terlihat di sisi yang lain. Kurva pembatas ini dibentuk oleh sejumlah data kritikal ketika bulan nampak sebagai lengkungan cahaya samar yang hanya bisa diidentifikasi lewat alat bantu optik seperti teleskop atau teodolit.

Implementasinya, jika pada saat matahari terbenam pasca konjungsi ternyata bulan memiliki $a_{D}$ tertentu yang nilainya lebih kecil dibanding $a_{D}$ minimum dalam tabel 4 untuk kolom DAz yang sama, maka lengkungan sabit bulan tidak akan terlihat meskipun dilangsungkan observasi dengan alat bantu optik terbaik sekalipun. Sebaliknya jika bulan memiliki $a_{D}$ tertentu yang lebih besar dibanding $a_{D}$ minimum dalam tabel 4 untuk kolom DAz yang sama, maka lengkungan sabit bulan berpotensi besar untuk terlihat khususnya jika kondisi langit mendukung. Lokalitas cuaca, digunakan tidaknya alat bantu optik dan terampil tidaknya pengamat menentukan apakah lengkungan sabit bulan yang secara teoritik berpotensi besar untuk terlihat ini bisa terlihat atau tidak dalam praktik observasi. 
Interpolasi kriteria RHI menunjukkan nilai $\mathrm{a}_{\mathrm{D}}$ terkecil ideal adalah $4,776^{\circ}$ (pada DAz 7,525 $5^{\circ}$ atau dibulatkan menjadi $5^{\circ}$. Nilai ideal ini cukup dekat dengan nilai $a_{D}$ terkecil menurut Ilyas (1988) yakni $4^{\circ}$. Namun nilai $a_{D}$ terkecil faktual dalam Basis Data Visibilitas Indonesia adalah sedikit lebih besar, yakni 5,8 ${ }^{\circ}$ atau dibulatkan menjadi $6^{\circ}$. Sehingga nilai $\mathrm{a}_{\mathrm{D}}$ terkecil faktual adalah $1^{\circ}$ lebih besar dibanding nilai $a_{D}$ terkecil ideal.

\section{Visibilitas bagi Kawasan Tropis}

Hampir seluruh data pada Basis Data Visibilitas Indonesia bersumber dari titiktitik observasi di Indonesia semata sehingga kriteria visibilitas Indonesia (kriteria RHI) terkesan sebagai kriteria lokal apabila dibandingkan dengan kriteria-kriteria visibilitas modern lainnya yang rata-rata bersifat global. Apalagi perbandingan antara kriteria visibilitas Indonesia (kriteria RHI) dengan kriteria visibilitas yang menggunakan variabel $a_{D}$ dan DAz seperti kriteria Fotheringham-Maunder dan kriteria Bruin menunjukkan perbedaan signifikan. Kurva kriteria visibilitas Indonesia (kriteria RHI) berupa parabola terbuka ke atas dengan nilai $a_{D}$ pada awalnya menurun seiring kian bertambahnya DAz hingga mencapai titik balik pada DAz 7,525 $5^{\circ}$ untuk kemudian menanjak kembali. Sebaliknya kurva kriteria FotheringhamMaunder dan Bruin berbentuk parabola terbuka ke bawah sehingga memiliki nilai $\mathrm{a}_{\mathrm{D}}$ terus menurun seiring kian bertambahnya DAz tanpa adanya suatu titik balik.

Tabel 5.

Perbandingan antara Kriteria Visibilitas Indonesia (kriteria RHI) dengan Kriteria Visibilitas Fotheringham-Maunder dan Bruin

\begin{tabular}{cccc}
\hline \multirow{2}{*}{ DAz $\left({ }^{\circ}\right)$} & \multicolumn{3}{c}{ ad Minimum $\left({ }^{\circ}\right)$} \\
\cline { 2 - 4 } & Indonesia (RHI) & Fotheringham-Maunder & Bruin \\
\hline 0 & 10,38 & 11,00 & 10,14 \\
1 & 9,00 & 10,94 & 10,25 \\
2 & 7,80 & 10,86 & 10,30 \\
3 & 6,80 & 10,76 & 10,29 \\
4 & 6,01 & 10,64 & 10,22 \\
5 & 5,41 & 10,50 & 10,09 \\
6 & 5,01 & 10,34 & 8,94 \\
7 & 4,80 & 10,16 & 8,80
\end{tabular}

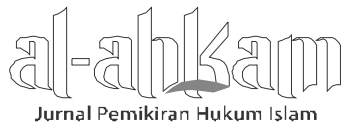


Muh. Ma'rufin Sudibyo

\begin{tabular}{cccc}
8 & 4,80 & 9,96 & 8,64 \\
9 & 5,00 & 9,74 & 8,47 \\
10 & 5,38 & 9,50 & 8,27 \\
\hline
\end{tabular}

Namun jika basis data visibilitas hilāl internasional masa kini, yakni basis data ICOP dan Yallop, diseleksi sehingga hanya menyisakan data-data yang berasal dari titik-titik observasi di kawasan tropis, maka data-data tersebut ternyata bersesuaian dengan kurva kriteria visibilitas Indonesia (kriteria RHI). Ini menunjukkan kriteria visibilitas Indonesia (kriteria RHI) bukanlah semata kriteria visibilitas dalam lingkup Indonesia, namun juga bisa diterapkan secara luas bagi kawasan tropis lainnya yakni yang terletak di antara garis $23,5^{\circ} \mathrm{LU}$ hingga $23,5^{\circ} \mathrm{LS}$. Hal ini didukung pula oleh basis data visibilitas hilāl dari kawasan tropis nonIndonesia, misalnya basis data Malaysia 2006 TU.

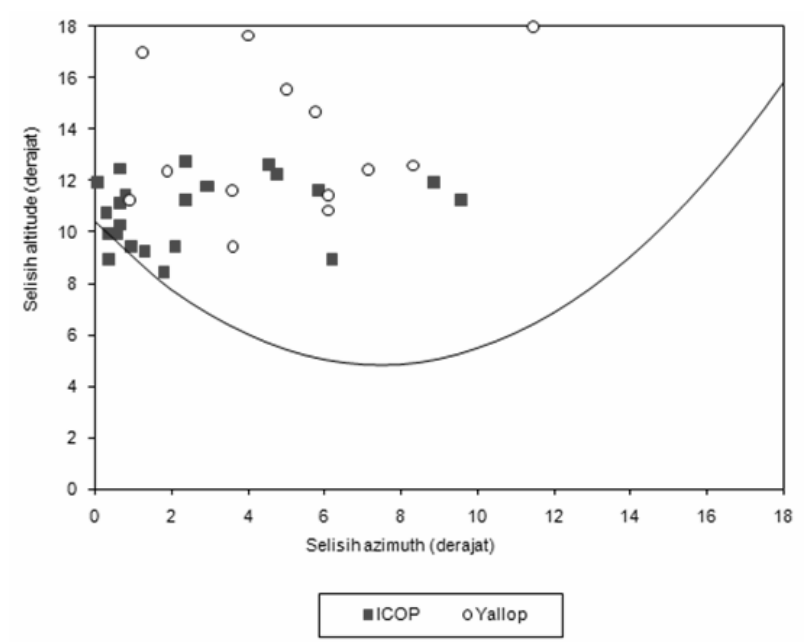

Gambar 5.

Plotting Data Observasi Positif dalam Basis Data ICOP dan Yallop menurut Variabel $a_{D}$ dan DAz Berbanding dengan Kurva Kriteria Visibilitas Indonesia (Kriteria RHI). Nampak bahwa Hampir Semua Data Tersebut Konsisten dengan Kurva Visibilitas

Perbedaan signifikan antara bentuk kriteria visibilitas Indonesia (kriteria RHI) dengan kriteria Fotheringham-Maunder dan Bruin seperti dinyatakan tabel 6 adalah konsekuensi dari tidak dibedakannya data observasi positif yang berbasis alat bantu optik maupun tidak di dalam pembentukan kriteria visibilitas Indonesia 
(kriteria RHI). Di sisi lain kriteria Fotheringham-Maunder dan Bruin hanya menggunakan data observasi positif yang tidak menggunakan alat bantu optik saja.

Hal ini diperkuat sejumlah data observasi terkini. Data observasi positif dari titik observasi berbasis teleskop yang ditunjang citra hilāl, misalnya dari Teluk Kemang (Malaysia), Semarang (Jawa Tengah), Bangkalan (Madura) dan Surakarta (Jawa Tengah) menunjukkan nilai $a_{D}$ yang lebih kecil dibanding aD minimum dalam kriteria Fotheringham-Maunder maupun Bruin adalah mungkin. Sebaliknya seluruh observasi tersebut memiliki aD yang lebih besar dibanding $\mathrm{aD}$ minimum kriteria visibilitas Indonesia (kriteria RHI), sehingga Data-data terbaru tersebut sekaligus menunjukkan konsistensi kriteria tersebut (tabel 7).

Tabel 6.

Data Observasi Terkini dan Perbandingannya dengan Kriteria Visibilitas Indonesia (Kriteria RHI)

\begin{tabular}{lcccc}
\hline \multicolumn{1}{c}{ Lokasi } & Tanggal & DAz & ad & ad Minimum \\
\hline Semarang & 19 Sep 2009 & 7,018 & 6,122 & 4,801 \\
Teluk Kemang & 12 Juli 2010 & 3,714 & 7,649 & 6,214 \\
Teluk Kemang & 6 Des 2010 & 1,913 & 8,136 & 7,894 \\
Bangkalan & 31 Juli 2011 & 5,337 & 7,121 & 5,250 \\
Surakarta & 18 Agt 2012 & 7,017 & 7,537 & 4,801 \\
\hline
\end{tabular}

\section{Visibilitas Hilāl Lokal dan Global}

Eksistensi Basis Data Visibilitas Indonesia juga memungkinkan untuk menguji implementasi kriteria Audah sebagai kriteria visibilitas modern bersifat global yang ditunjang oleh data observasi akumulatif berkuantitas mengesankan, yakni basis data ICOP. Nilai variabel $a_{D}$ dan $W$ untuk visibilitas positif disajikan dalam gambar 8 untuk langsung dibandingkan dengan kriteria Audah bagi tiga kondisi visibilitas, masing-masing kondisi hanya bisa dilihat dengan alat bantu optik $(-0,96$ $\geq \mathrm{V}>2,00$ ), bisa dilihat dengan alat bantu optik dan mungkin terlihat dengan mata tanpa alat bantu optik $(2,00 \geq \mathrm{V}>5,65)$ dan yang mudah dilihat mata tanpa alat bantu optik $(V \geq 5,65)$.

Secara mengagumkan Basis Data Visibilitas Indonesia ternyata konsisten dengan kriteria Audah dimana tidak ada data positif yang memiliki nilai $\mathrm{V}<-0,96$. 
Dengan kata lain kriteria Audah yang bersifat global pun ternyata dapat diimplementasikan dalam lingkup lokal khususnya di Indonesia.

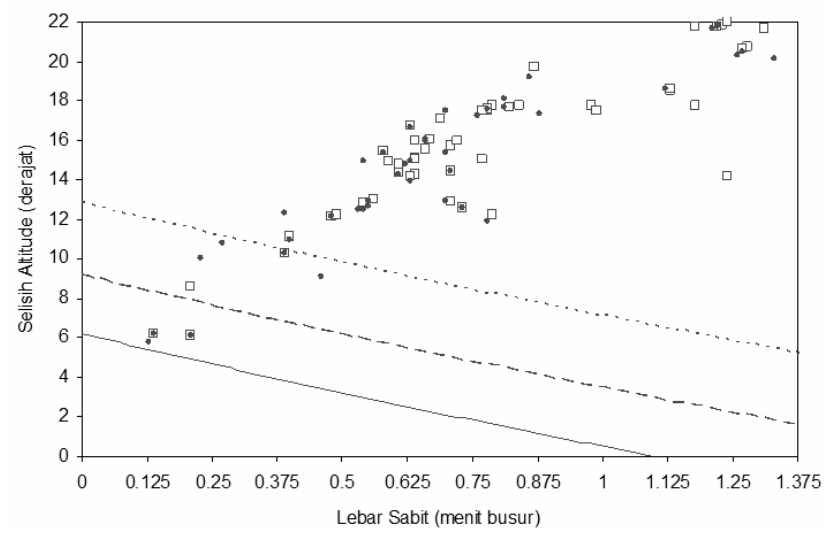

Gambar 6.

Plotting Data Observasi Positif dalam Basis Data Visibilitas Indonesia menurut Variabel a dan W Berbanding terhadap Kriteria Audah. Dari Bawah ke Atas, Ketiga Kurva dalam Gambar Merupakan Himpunan Titik-titik dengan V=-0,96; 2 dan 5,65.

Bagaimana konsistensi kriteria visibilitas Indonesia (kriteria RHI) terhadap kriteria Audah juga dapat dilihat pada bentuk garis ILDL (International Lunar Date Line)-nya. Garis ILDL dalam kriteria visibilitas Indonesia (kriteria RHI) merupakan himpunan titik-titik koordinat dengan nilai $\mathrm{a}_{\mathrm{D}}$ tepat sama dengan nilai 0,099DAz ${ }^{2}$ $1,490 \mathrm{DAz}+10,382$. Sementara garis ILDL dalam kriteria Audah adalah himpunan titik-titik koordinat dengan nilai V tepat sama dengan -0,96. Jika garis ILDL kriteria Audah dibatasi hanya pada kawasan tropis, maka garis tersebut berdekatan atau malah berimpit dengan garis ILDL kriteria visibilitas Indonesia (kriteria RHI). Konsistensi ini menunjukkan jika kriteria global (seperti halnya kriteria Audah) diimplementasikan dalam lingkup terbatas seperti di kawasan tropis, maka ia tetap konsisten dengan kriteria lokal-regional (seperti halnya kriteria visibilitas Indonesia/kriteria RHI).

\section{Redefinisi Hilāl dan Reposisinya dalam Fase-fase Bulan}

Selama ini hilāl secara kualitatif dianggap sebagai bulan dalam fase sabit yang paling muda/paling tipis, sehingga muncul persepsi bahwa hilāl adalah bagian dari bulan sabit. Sementara bulan sabit sendiri adalah bulan yang telah melewati tahap konjungsi namun memiliki fase lebih kecil dibandingkan bulan separuh. Namun 
bulan sabit dalam kondisi seperti apa yang bisa dinamakan hilāl sejauh ini belum terdefinisikan dengan jelas.

Jika mengacu pada nilai fase bulan, maka bulan sabit adalah bulan yang memiliki batas bawah fase bulan pada saat konjungsi (yakni dengan fase 0\% hingga 0,19\% bergantung kepada $\mathrm{a}_{\mathrm{L}}$ pada saat konjungsi) dan batas atasnya adalah fase bulan yang bertepatan dengan bulan separuh (fase 50\%). Dengan tidak terdefinisikannya hilāl secara kuantitatif maka hilāl bisa salah diyakini sebagai bulan sabit, sementara bulan sabit sendiri berumur cukup lama (rata-rata 7,5 hari terhitung sejak konjungsi bulanmatahari hingga saat fase bulan mencapai 50\%). Dengan umur yang cukup lama, maka menyamaratakan hilāl dengan bulan sabit jelas bakal komplikatif mengingat satu tanggal Hijriyyah hanya berlaku untuk satu hari saja.

Maka definisi hilāl sebaiknya dipisahkan dari definisi bulan sabit, yang membuat hilāl mempunyai definisi kuantitatif tersendiri yang berbeda apabila dibandingkan dengan definisi kuantitatif bulan sebagai bulan sabit. Dengan demikian seperti halnya fase bulan sabit maka hilāl adalah salah satu fase dari bulan, yang dinamakan fase hilāl. Untuk itu perlu dirumuskan batas antara bulan dalam fase hilāl dengan bulan dalam fase bulan sabit. Batas tersebut dinamakan batas atas hilāl. Sebaliknya juga perlu dirumuskan batas bawah hilāl dan apakah berimpit dengan konjungsi ataukah fenomena lain. Perumusan batas atas dan batas bawah yang tegas sekaligus untuk menghilangkan kerancuan yang selama ini terjadi antara yang mengasumsikan hilāl sudah lahir dengan hilāl sudah berpotensi terlihat.

Perumusan batas atas dan batas bawah bagi fase hilāl membutuhkan parameter tertentu. Dua parameter paling sederhana adalah: terlihatnya bulan oleh mata manusia, dan terbenamnya matahari. Meskipun sederhana, parameter pertama (terlihatnya bulan oleh mata manusia) berlatar belakang cukup kompleks. Konsep fotometrik, ${ }^{36}$ memperlihatkan terlihatnya bulan lewat mata manusia pada senja pasca matahari terbenam bisa diaproksimasi dengan situasi dimana bulan lebih cemerlang dibanding langit senja. bulan dapat terlihat ketika nilai kontras bulan masih lebih besar dibanding nilai kontras langit senja. Besarnya nilai kontras bulan bergantung pada intensitas cahaya tampak dari bulan yang sampai di permukaan

${ }^{36}$ Sultan, Hijri Calendar \& Lunar Visibility, The $3^{\text {rd }}$ Islamic Astronomical Conference, Astronomical Applications in Islamic Shari'a. Amman, Oct 20th - 22nd, 2003, h. 2. Baca juga: Arumaningtyas, Studi Kecemerlangan Langit Terhadap Visibilitas Hilāl, skripsi, tidak dipublikasikan, Bandung: Program Studi Astronomi F-MIPA ITB, 2009, h. 45 
bumi ${ }^{37}$ dibanding intensitas cahaya tampak langit senja, yang dipengaruhi faktorfaktor air, debu dan molekul-molekul udara dalam atmosfer. Secara empiris situasi tersebut telah diaproksimasi oleh kriteria visibilitas modern yang valid dan reliabel.

Berpatokan pada konsep fotometrik semacam itu, maka batas bawah hilāl adalah situasi di mana nilai kontras bulan tepat sama atau lebih besar dibanding nilai kontras langit senja pasca terbenamnya matahari. Sementara batas atas hilāl adalah situasi dimana nilai kontras bulan tepat sama atau lebih besar dibanding nilai kontras langit senja tepat pada saat terbenamnya matahari. Baik batas atas maupun batas bawah tersebut mengacu pada spektrum cahaya tampak.

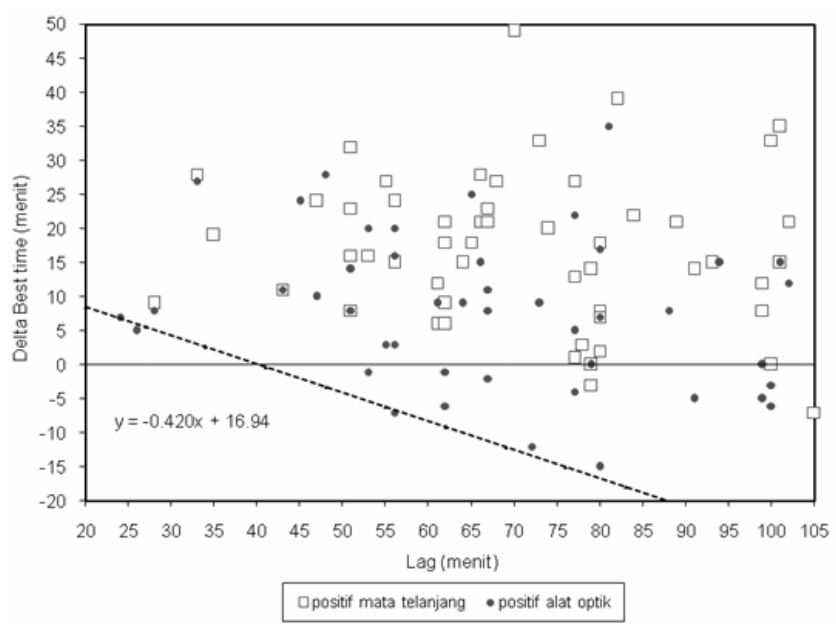

\section{Gambar 7. \\ Plotting data Observasi Positif dalam Basis Data Visibilitas Indonesia menurut Variabel $T_{b}$ dan Lag. Garis Putus-putus adalah Kurva Persamaan 8.}

Salah satu variabel penting dalam membentuk definisi kuantitatif hilāl adalah best time. ${ }^{38}$ Konsep best time pertama kali diusulkan Yallop dan adalah elemen khas observasi hilāl karena hanya muncul dalam data observasi positif. Dengan menabulasikan best time $\left(\mathrm{T}_{\mathrm{b}}\right)$ terhadap Lag bulan dalam Basis Data Visibilitas Indonesia maka diperoleh persamaan matematis pembatas:

\footnotetext{
37Yakni cahaya bulan yang telah mengalami hamburan dan serapan oleh lapisan-lapisan udara atmosfer bumi dalam kondisi cuaca sempurna.

${ }^{38}$ Best time: waktu (dalam satuan menit) saat bulan mulai terlihat pasca matahari terbenam.
} 


$$
T_{b}=-0,42 \operatorname{Lag}+16,941+T_{\text {sunset }}\left(\mathrm{R}^{2}=0,9899\right) \quad \text { *pers. (8) }
$$

Jika pada persamaan (8) diterapkan kondisi $\mathrm{T}_{\mathrm{b}}-\mathrm{T}_{\text {sunset }}=0$ (atau $\mathrm{T}_{\mathrm{b}}=\mathrm{T}_{\text {sunset}}$ ) maka diperoleh hasil Lag $=40$ menit. Dengan kata lain jika bulan pasca konjungsi memiliki Lag = 40 menit pada saat terbenamnya matahari, maka lengkungan sabit bulan terlihat tepat saat matahari terbenam sehingga Lag $=40$ menit menjadi batas atas hilāl yang ideal.

Menggunakan langkah serupa, maka jika pada persamaan (8) diterapkan kondisi $\mathrm{T}_{\mathrm{b}}-\mathrm{T}_{\text {sunset }}=\mathrm{x}$ maka akan diperoleh hasil Lag $=\mathrm{x}=12$ menit. Dengan kata lain jika bulan pasca konjungsi memiliki Lag $=12$ menit pada saat terbenamnya matahari, maka lengkungan sabit bulan terlihat tepat saat bulan terbenam. Namun dalam praktiknya situasi tersebut tidak akan terjadi sehingga kondisi Lag $=12$ menit tidak akan mungkin tercapai. Dalam Basis Data Visibilitas Indonesia, nilai Lag terkecil empiris saat lengkungan sabit bulan terlihat adalah 24 menit. Sebagai pembanding dalam basis data ICOP nilai Lag terkecil empiris adalah 21 menit. Sehingga terlihat bahwa meskipun Basis Data Visibilitas Indonesia merupakan basis data lokalregional, dalam parameter Lag terkecil empiris ternyata tidak berselisih jauh dibandingkan basis data visibilitas internasional yang bersifat global.

Menggunakan hubungan matematis:

$$
\begin{aligned}
& a_{S} \approx \frac{1}{4} \operatorname{Lag} \\
& a_{D}=a_{S} \cos \varphi
\end{aligned}
$$

dan dengan $\varphi \approx 0^{\circ}$ (karena Indonesia berada di kawasan tropis) maka pada saat Lag $=24$ menit diperoleh $\mathrm{a}_{\mathrm{D}} \approx 6^{\circ}$. Nilai $\mathrm{a}_{\mathrm{D}} \approx 6^{\circ}$ hampir sama dengan nilai $\mathrm{a}_{\mathrm{D}}$ terkecil faktual dalam Basis Data Visibilitas Indonesia yakni 5,8 . Dari pertidaksamaan kriteria visibilitas Indonesia (kriteria RHI) yakni $a_{D} \geq 0,099 \mathrm{DAz}^{2-}$ $1,490 \mathrm{DAz}+10,382$ telah diketahui bahwa nilai aD terkecil faktual $5,8^{\circ}$ tersebut tidak berbeda jauh dengan nilai aD terkecil ideal dan nilai tersebut hanyalah bagian dari suatu kolom DAz tertentu, sementara pertidaksamaan kriteria visibilitas Indonesia (kriteria RHI) memiliki rentang DAz cukup lebar. Karena itu cukup beralasan untuk menyatakan bahwa batas bawah hilāl adalah pertidaksamaan 
kriteria visibilitas Indonesia (kriteria RHI): $a_{D} \geq 0,099 D A z^{2}-1,490 \mathrm{DAz}+10,382$. Sementara batas atas hilāl adalah Lag $=40$ menit, yang apabila ditransformasikan dengan persamaan (9) akan identik dengan $\mathrm{a}_{\mathrm{D}} \approx 10^{\circ}$.

Dengan Lag $=40$ menit $\left(\mathrm{a}_{\mathrm{D}} \approx 10^{\circ}\right)$ sebagai batas atas hilāl, maka hilāl memiliki rentang umur pendek yakni sekitar 20 jam sehingga tidak melebihi batasan umur satu hari (rata-rata 24 jam). Pendeknya umur hilāl berdasarkan konsep ini cukup bermanfaat dalam implementasinya. Misalnya, apabila Indonesia pada suatu waktu mengalami situasi dimana bulan pasca konjungsi di kala matahari terbenam memiliki $a_{D}$ yang lebih kecil dibanding nilai pertidaksamaan $a_{D} \geq 0,099 D^{2} z^{2}$ 1,490DAz+10,382, maka bulan belum berada dalam fase hilāl dan konsekuensinya tanggal 1 Hijriyyah pun belum terjadi. Namun dalam 24 jam kemudian (ketika matahari terbenam) Indonesia akan mengalami situasi dimana bulan memiliki Lag $>40$ menit $\left(\mathrm{a}_{\mathrm{D}} \approx 10^{\circ}\right)$, maka bulan sudah melewati fase hilāl dan sudah bertada dalam fase bulan sabit sehingga tanggal 1 Hijriyyah bagi Indonesia secara otomatis terjadi pada saat itu dan tidak ada istilah hilāl hari kedua.

Apabila parameter terlihat oleh mata manusia tidak dipergunakan, maka situasinya akan sangat berbeda. Secara matematis lengkungan sabit bulan sudah ada (lahir) tepat pada saat konjungsi mengingat dalam peristiwa tersebut bulan selalu berelongasi terhadap matahari (kecuali pada saat Gerhana matahari Total $^{39}$ ). Elongasi bulan pada saat konjungsi bernilai antara $0^{\circ}$ hingga $5^{\circ}$ yang berkorelasi dengan nilai lebar sabit bulan teoritik antara $0^{\prime}$ hingga 0,06' dengan panjang busur lengkungan sabit bulan teoritik tepat $180^{\circ}$. Fakta bahwa lengkungan sabit bulan sudah ada saat konjungsi didukung pula oleh data observasi, salah satunya observasi Legault (14 April 2010 TU) meski lengkungan tersebut tidak akan teridentifikasi apabila observasi dilangsungkan dalam spektrum cahaya tampak. Dengan lengkungan sabit bulan sudah muncul pada saat konjungsi, maka asumsi bahwa lengkungan sabit bulan baru lahir dalam beberapa saat pasca konjungsi pun gugur.

Perumusan definisi kuantitatif hilāl dengan berdasarkan pada nilai kontras bulan berbanding langit senja dalam spektrum cahaya tampak membawa konsekuensi tersendiri, yakni munculnya situasi dimana nilai kontras bulan lebih

\footnotetext{
${ }^{39} \mathrm{Hal}$ tersebut bisa terjadi karena definisi konjungsi bulan-matahari adalah saat bulan dan matahari terletak dalam satu garis bujur ekliptika yang sama. Pada saat itu bulan bisa terletak pada lintang ekliptika yang berbeda dibanding matahari. Lihat Badan Hisab Rukyat Kemenag Pusat, Almanak Hisab Rukyat, 2010, h. 57
} 
kecil dibanding langit senja meskipun bulan masih ada di langit saat terbenamnya matahari pasca konjungsi (dimana $\mathrm{aD}>0, \mathrm{~h}>0$ dan Lag $>-2$ menit). Dalam situasi tersebut bulan tidak akan terlihat oleh mata manusia dan disini diusulkan untuk didefinisikan tersendiri sebagai fase bulan gelap, yang terpisah dari fase hilāl dan fase bulan sabit. Dengan demikian nama-nama fase bulan sejak terjadinya konjungsi hingga bulan separuh sebaiknya didefinisikan ulang dalam urutan sebagai berikut:

Tabel 7.

Redefinisi Nama-nama Fase Bulan

\begin{tabular}{|c|l|l|}
\hline No & \multicolumn{1}{|c|}{ Nama Fase } & \multicolumn{1}{c|}{ Deskripsi } \\
\hline 1 & Bulan gelap & $\begin{array}{l}\text { Bulan sejak saat konjungsi hingga elemen posisinya tepat } \\
\text { kurang dari pertidaksamaan } \mathrm{a}_{\mathrm{D}} \geq 0,099 \mathrm{DAz} \mathrm{z}^{2}-1,490 \mathrm{DAz}+ \\
10,382 .\end{array}$ \\
\hline 2 & Hilāl & $\begin{array}{l}\text { Bulan yang elemen posisinya memenuhi pertidaksamaan } \\
\text { aD } \geq 0,099 \mathrm{DAz} \mathrm{z}^{2}-1,490 \mathrm{DAz}+10,382 \text { hingga Lag }<40 \\
\text { menit. }\end{array}$ \\
\hline 3 & Bulan sabit & $\begin{array}{l}\text { Bulan dengan Lag } \geq 40 \text { menit hingga fasenya tepat } \\
\text { kurang dari 50\%. }\end{array}$ \\
\hline 4 & Bulan separuh & Bulan dengan fase tepat senilai 50\%. \\
\hline
\end{tabular}

Perumusan definisi kuantitatif hilāl berbasiskan nilai kontras bulan berbanding langit senja dalam spektrum cahaya tampak juga menyajikan peluang dalam menginterpretasikan kembali teks "..fa'in ghumma.." yang termaktub dalam sejumlah sabda Rasulullah $\mathrm{SAW}^{40}$. Selama ini teks tersebut di Indonesia diterjemahkan menjadi ".. terhalangi (karena mendung atau hujan)." Namun jika ditinjau lebih lanjut secara geografis, maka frasa ".. (karena mendung atau hujan).." hanya khas bagi lingkungan geografis tertentu seperti halnya kawasan tropis beriklim maritim layaknya Indonesia, yang memiliki kelembaban udara cukup tinggi dan jumlah hari hujan pertahun cukup besar. Sebaliknya Jazirah Arabia, ruang hidup Rasulullah SAW dan generasi pertama Muslim, merupakan kawasan kontinental yang beriklim gurun dengan kelembaban udara sangat rendah dan

40Misalnya Hadis no. 1906 dan 1909 dalam Șahịh al-Bukhārī dan Hadis no. H (1080)-03 dan H (1083)-17 dalam Șaḥịh Muslim. Secara keseluruhan ada 14 Hadis șaḥịh yang senada (memuat teks "fain ghumma"). 
jumlah hari hujan per tahun sangat sedikit (tabel 9). Jadi interpretasi teks "fain ghumma" sebagai ... terhalangi mendung atau hujan ... terasa kurang tepat bagi Jazirah Arabia dan kawasan segeografis lainnya.

Interpretasi tersebut pula yang selama ini kerap menimbulkan batu sandungan, mengingat langit di sejumlah titik observasi tertutupi mendung atau dalam kondisi hujan sehingga bulan dalam fase hilāl dan sebaliknya maka bulan sebagai hilāl disimpulkan tak terdeteksi (tak terlihat). Padahal penarikan kesimpulan tersebut belum memperhitungkan titik-titik dimana langit tak tertutupi mendung/ hujan yang tidak melaksanakan observasi.

Tabel 8.

\section{Perbandingan Karakter Iklim Jakarta (Indonesia) dengan Makkah dan Madinah (Saudi Arabia) ${ }^{41}$}

\begin{tabular}{clccc}
\hline No & \multicolumn{1}{c}{ Parameter } & Jakarta & Makkah & Madinah \\
\hline 1 & $\begin{array}{l}\text { Jumlah hari hujan rata-rata } \\
\text { tahun. }\end{array}$ & 119 & 12 & 50 \\
2 & $\begin{array}{l}\text { Kelembaban rata-rata sore hari (\%). } \\
3\end{array}$ & 61 & 31 & 16 \\
4 & Kelembaban rata-rata pagi hari (\%). & 91 & 62 & 32 \\
\hline
\end{tabular}

Perumusan definisi kuantitatif hilāl dengan berbasiskan perbandingan nilai kontras bulan berbanding langit senja dalam spektrum cahaya tampak memberikan peluang untuk menginterpretasikan kembali teks tersebut. Yakni bahwa karena adanya fase bulan gelap yang mendahului fase hilāl, maka teks "fain ghumma" bisa diterjemahkan ulang menjadi “..cahaya (bulan) yang tertutupi cahaya (senja).." Hal ini juga didasarkan pada fakta bahwa dalam fase bulan gelap, terjadi situasi dimana intensitas cahaya bulan lebih rendah dibanding intensitas cahaya langit senja dalam spektrum cahaya tampak, atau nilai kontras bulan yang lebih rendah dibanding langit senja. Reinterpretasi ini memosisikan bulan dalam

\footnotetext{
${ }^{41}$ Bersumber dari http://www.weatherbase.com/ diunduh 10 Juni 2012, yang dirata-ratakan dalam 10 tahun terakhir. Karakter iklim pada 14 abad silam (yakni di masa hidup Rasulullah SAW) belum diketahui, namun dengan mengacu kurva aktivitas matahari dalam 15 ribu tahun terakhir dan prinsip the present is key to the past, maka pola iklim saat itu kemungkinan besar tidak berbeda dengan kini.
} 
fase hilāl dipengaruhi oleh atmosfer bumi, namun menyubstitusi faktor-faktor meteorologis (cuaca dan iklim) yang sulit diprediksi dengan faktor non-meteorologis rata-rata (sifat optis atmosfer bumi) yang relatif lebih mudah diprediksi.

\section{Kesimpulan}

Observasi hilāl dan hilāl tua secara terus-menerus telah dilaksanakan oleh jejaring observasi Rukyatul Hiläl Indonesia (jejaring RHI) dengan tujuan untuk menghimpun data-data observasi hilāl yang valid dan reliabel khususnya untuk Indonesia. Observasi menghasilkan serangkaian data visibilitas positif dan negatif yang selanjutnya dihimpun dalam Basis Data Visibilitas Indonesia.

Analisis data menghasilkan kriteria visibilitas modern empiris yang disebut Kriteria Visibilitas Indonesia (kriteria RHI) dalam bentuk $a_{D} \geq 0,099$ DAz $^{2}-1,490$ $\mathrm{DAz}+10,382$. Meski berdasarkan basis data lokal, namun kriteria ini konsisten dengan basis data visibilitas internasional seperti Yallop dan ICOP, sepanjang diseleksi hanya untuk data-data yang bersumber dari kawasan tropis. Kriteria ini pun tetap konsisten manakala dibandingkan dengan basis data visibilitas tropis yang bukan berasal dari Indonesia sehingga merupakan kriteria visibilitas nasional dan regional. Meski berbeda bentuk apabila dibandingkan kriteria visibilitas modern dengan variabel sejenis seperti kriteria Fotheringham-Maunder dan Bruin, bentuk kriteria visibilitas Indonesia (kriteria RHI) tetap bisa diterima karena didukung oleh data-data observasi terkini.

Sebuah definisi kuantitatif hilāl bagi kawasan tropis telah diusulkan sebagai fungsi dari kontras bulan terhadap kontras langit senja. Hilāl diusulkan sebagai bulan pasca konjungsi yang memiliki batas bawah berupa kriteria visibilitas Indonesia (kriteria $\mathrm{RHI})$ dan batas atas berupa Lag $=40$ menit $\left(\mathrm{a}_{\mathrm{D}} \approx 10^{\circ}\right)$. Jika diurutkan sejak konjungsi hingga bulan separo, maka fase-fase bulan diusulkan untuk menjadi: bulan gelap, hilāl, bulan sabit dan bulan separo.[a]

\section{DAFTAR PUSTAKA}

Arumaningtyas, Studi Kecemerlangan Langit Terhadap Visibilitas Hilāl, skripsi (tidak dipublikasikan), Bandung: Program Studi Astronomi F-MIPA ITB, 2009.

Audah, New Criterion for Lunar Crescent Visibility, Exp. astr., 18, 2004.

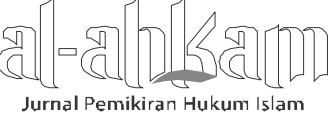


Muh. Ma'rufin Sudibyo

Djamaluddin, "Re-evaluation of Hilāl Visibility in Indonesia", dalam Warta LAPAN, vol. 2 no. 4, 137-138, Oktober 2000.

Djamaluddin, "Astronomi Memberi Solusi Penyatuan Ummat", Booklet LAPAN, 2011.

Dogget, et.al., Lunar Crescent Visibility. Icarus, 1994.

Fatoohi et.al., The Danjon Limit of First Visibility of The Lunar Crescent. The Observatory, 1998.

Ilyas. Lunar Crescent Visibility Criterion and Islamic Calendar, Q. J. R. astr. Soc., 1994.

Izzuddin, Ahmad, Fiqih Hisab Rukyah, Jakarta: Penerbit Erlangga, 2007.

Kementerian Agama RI, Keputusan Lokakarya Mencari Kriteria Format Awal Bulan di Indonesia, 2011.

Parker, Just The Facts: Tata Surya, diterjemahkan Astranto. Jakarta: Erlangga, 2006.

Schaefer, The Length of Lunar Month, Archaeoastronomy, 17, S33-S41. 1992.

Schaefer, Lunar Crescent Visibility, Q. J. R. astr. Soc., vol. 37, 1996.

Sudibyo, Arkanuddin \& Sugeng Riyadi, Observasi Hilāl 1427-1430 H (2007-2009 M) dan Implikasinya untuk Kriteria Visibilitas di Indonesia, Prosiding Seminar Nasional Mencari Solusi Kriteria Visibilitas Hilāl dan Penyatuan Kalender Islam dalam Perspektif Sains dan Syariah, Observatorium Bosscha (Lembang), 19 Desember 2009.

Sudibyo, Evaluation of the Danjon's and Sulthan's Crescent Length Models with the 1427-1430 AH (2007-2009 CE) Young/Old Crescent Observations from Indonesia, Prosiding The 2010 Conference of Earth and Space Sciences, ITB (Bandung), 9-10 Januari 2010.

Sudibyo, Variasi Lokal dalam Visibilitas Hilāl: Observasi Hilāl di Indonesia pada 2007-2009, Prosiding Pertemuan Ilmiah Tahunan XXV Himpunan Fisika Indonesia Jateng-DIY 2011, Unsoed (Purwokerto), 9 April 2009.

Sudibyo, Visibilitas Hilāl di Daerah Tropis, Seminar Himpunan Astronomi Indonesia 2011 dalam rangka 60 tahun Pendidikan Astronomi, ITB Bandung, 27 Oktober 2011.

Sultan, Hijri Calendar \& Lunar Visibility: Physical Approach. The $3^{\text {rd }}$ Islamic Astronomical Conference, Astronomical Applications in Islamic Shari'a. Amman, Oct 20 th $-22^{\text {nd }}, 2003$.

Taufiq, Sistem Informasi Hisab Rukyat. Prosiding Seminar Nasional Mencari Solusi Kriteria Visibilitas Hilāl dan Penyatuan Kalender Islam dalam Perspektif Sains dan Syariah, Observatorium Bosscha (Lembang), 19 Desember 2009.

142 Volume 24, Nomor 1, April 2014

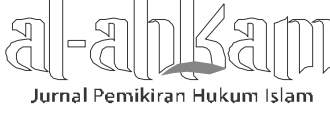


Williams, Geological Constraints on The Precambrian History of Earth's Rotation and The Moon's Orbit. Rev. of. Geophysics, 38, 2000.

Yallop, A Method for Predicting the First Sighting of The New Crescent Moon. NAO Technical Note no. 69, 1997.

Internet:

Azhari, http://www.ilmufalak.org/ diunduh pada 10 Desember 2009.

Legault, World Record: The Youngest New Moon Crescent, April 14, 2000. Astrosurf, http://astrosurf.com/legault/new_moon_2010april14.html, diunduh pada 20 April 2010.

Qamaruddin, Al-Jazeerah TV Show: Specify The Islamic Lunar Months [2/1/2008]. ICOP http://icoproject.org/ diunduh pada 30 Januari 2008.

Qureshi, Computational Astronomy and The Ealiest Visibility of Lunar Crescent, ICOP, 2005. http://icoproject.org/ diunduh pada 30 Januari 2008.

Zainal, A Selective Literature Review of Young Moon Crescent Visibility Studies, ICOP, 2001. http://icoproject.org/ diunduh pada 30 Januari 2008. 
144 Volume 24, Nomor 1, April 2014 